\title{
AMINO ACID REQUIREMENTS FOR CLEAVAGE OF THE RABBIT OVUM
}

\author{
JOSEPH C. DANIEL, JR AND JOHN D. OLSON \\ Institute for Developmental Biology, University of Colorado, Boulder, Colorado
}

(Received 28th October 1967)

\begin{abstract}
Summary. The amino acids essential for cleavage of the rabbit ovum were determined by appraisal of the growth of eggs in vitro in defined medium deficient in specific amino acids. The first cleavage will occur in amino acid-free medium but the second requires cysteine, tryptophane, phenylalanine, lysine, arginine, and valine. Subsequent cleavage to the morula stage requires the addition of methionine, threonine and glutamine.
\end{abstract}

The amino acid requirements for pre-implantation stages of the mouse have been studied by methods that permit the growth of these embryos in vitro (Whitten, 1956, 1957; Brinster, 1965; Brinster \& Thomson, 1966; Gwatkin, 1966). The only comparable study that has been done with rabbit embryos has been on the 5-day blastocyst stage (Daniel \& Krishnan, 1968). The purpose of this communication is to describe the results of studies designed to identify those amino acids which are essential for early cleavage of the rabbit ovum.

Fertilized ova were flushed from the oviducts with Saline F (Ham \& Puck, 1962) at $18 \mathrm{hr}$ p.c. The eggs were cultured for $30 \mathrm{hr}$ in defined culture medium F10 (Ham, 1963) with specific amino acids deleted. Media lacking groups of five amino acids were used initially to facilitate the screening; then individual amino acids from groups which did not allow normal development were screened. Controls were run in each experiment with embryos cultured in complete F10 medium and in F10 free of amino acids. Five or six ova were used for each determination.

In vivo, by $48 \mathrm{hr}$ p.c., the average rabbit ovum is composed of eighteen cells (Daniel 1964). Normally by $30 \mathrm{hr}$ in culture in F10, rabbit ova, explanted from the mother at $18 \mathrm{hr}$ p.c., will have completed four cleavages (occasionally only three) and so be composed of at least eight but usually sixteen cells. In amino acid-free $F 10$, ova typically cleave no more than one time. In each experiment the growth of the ova in specific amino acid-deficient medium was compared to that occurring in the two types of controls and recorded as being equal to one or the other. Thus, any medium supporting growth comparable to full F10 was considered sufficient, and therefore its deficient amino acid unessential. If the number of cells composing the ova was only two after $30 \mathrm{hr}$ in vitro, the medium was obviously insufficient and therefore lacked an essential amino acid. After the amino acids were determined, ova were then grown in 
F10 containing only the essential ones or the essential ones plus the questionable ones.

The results of the screening experiments are listed in Table 1. They show conclusively that cysteine, tryptophane, phenylalanine, lysine, arginine and valine are essential while histidine, tyrosine, leucine, serine, glycine, aspartic acid, glutamic acid, asparagine, alanine, proline and isoleucine are not essential.

\section{TABLE 1}

GLEAVAGE OF RABBIT OVA in vitro IN MEDIA DEFIGIENT IN ONE OF THE FOLLOWING AMINO AGIDS

\begin{tabular}{|c|c|c|c|}
\hline $\begin{array}{l}\text { Glycine } \\
\text { Alanine } \\
\text { Valine } \\
\text { Leucine } \\
\text { Isoleucine } \\
\text { Serine } \\
\text { Threonine } \\
\text { Cysteine } \\
\text { Methionine } \\
\text { Aspartic acid }\end{array}$ & 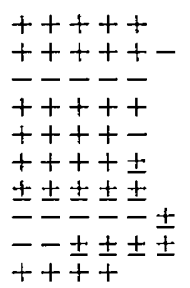 & $\begin{array}{l}\text { Asparagine } \\
\text { Glutamic acid } \\
\text { Glutamine } \\
\text { Arginine } \\
\text { Lysine } \\
\text { Histidine } \\
\text { Phenylalanine } \\
\text { Tyrosine } \\
\text { Tryptophane } \\
\text { Proline }\end{array}$ & $\begin{array}{l}++++- \pm \\
+++ \pm \pm \\
- \pm \pm \pm \pm \\
-- \pm \pm \pm \\
----- \\
++++ \pm \\
---- \pm \\
++++- \\
----- \\
++++ \pm\end{array}$ \\
\hline
\end{tabular}

Each symbol represents one ovum: + , development equal to the controls in full F10 (eight to sixteen cells); - , development equal to the controls in amino acid-free F10 (one to two cells); \pm , development to four cells only.

Three of the amino acids tested, namely methionine, threonine, and glutamine, gave questionable results. Their absence caused some inhibition of the embryos so that these ova never went beyond the four-cell stage and were therefore at least one cleavage behind the controls at the end of the culture period.

In the combination experiments the six essential amino acids alone supported growth only to the four-cell stage, while these six plus the three questionable ones supported continuous growth to at least the early morula stage in vitro at a rate equal to that of the controls in full F10 medium.

One may conclude that the first cleavage of the rabbit ovum can take place in the absence of any exogenous amino acids in the supporting medium, but for cleavage to continue to the four-cell stage, cysteine, tryptophane, phenylalanine, lysine, arginine and valine are essential. For the ovum to cleave beyond the four cells (at least to the early morula stage) the same six just mentioned are required as well as methionine, threonine and glutamine.

The earlier study (Daniel \& Krishnan, 1967) shows that for growth of the 5-day blastocyst stage in vitro, tryptophane, phenylalanine, lysine, arginine, valine, methionine, threonine, serine, leucine, histidine and possibly tyrosine are essential. It will be noted that this list includes all of those noted above, except cysteine and glutamine, plus the addition of four new amino acids. Thus one notes that, with progressive development of the rabbit ovum through cleavage and into the blastocyst stages, the requirement for specific amino acids undergoes continual change, new ones being added at certain stages and other ones that were essential in the early phases becoming unessential later. This observation might reflect changes in the metabolism of the embryo, in the kinds of 
proteins being synthesized and/or the capacity of the embryo to store some of the amino acids that may be essential to it.

The situation just described for the rabbit embryo appears to be different from that described earlier for the mouse embryo (Brinster, 1965; Brinster \& Thomson, 1966). The mouse has no specific amino acid requirement for cleavage to the blastocyst stage; any one amino acid present in the culture medium presumably supplies the nitrogen source needed. By the blastocyst stage, however, Gwatkin (1966) found that for cellular outgrowth to occur at least five amino acids had become essential and five others could be classified as beneficial. In general the specific amino acids which he lists are the same as observed here for development of the rabbit embryo.

This research was supported by the United States Atomic Energy Commission, contract No. AT (11-1)-1597.

\section{REFERENCES}

BRINSTER, R. L. (1965) Studies on the development of mouse embryos in vitro. III. The effect of fixednitrogen source. 7. exp. Zool. 158, 69.

Brinster, R. L. \& Thomson, J. L. (1966) Development of eight-cell mouse embryos in vitro. Expl Cell Res. 42, 308.

Daniel, J. C., Jr (1964) Early growth of rabbit trophoblast. Am. Nat. 98, 85.

Daniel, J. C., JR \& Krishnan, R. S. (1967) Amino acid requirements for growth of the rabbit blastocyst in vitro. 7. cell. comp. Physiol. 70, 155.

Gwatkin, R. B. L. (1966) Amino acid requirements for attachment and outgrowth of the mouse blastocyst in vitro. F. cell. comp. Physiol. 68, 335.

HAM, R. G. (1963) An improved nutrient solution for diploid Chinese hamster and human cell lines. Expl Cell Res. 29, 515.

HAM, R. G. \& PucK, T. T. (1962) Quantitative clonal growth of isolated mammalian cells. Meth. Enzym. 5, 90.

WhrtTEN, W. K. (1956) Culture of tubal mouse ova. Nature, Lond. 177, 96.

Whrtes, W. K. (1957) Culture of tubal ova. Nature, Lond. 179, 1081. 